J. Perinat. Med. $12(1984) 19$

\section{Further study of the inhibition of premature labor by indomethacin Part I}

\author{
Henryk Zuckerman, Eliezer Shalev, Gabriel Gilad, Eliahu Katzuni* \\ Department of Obstetrics and Gynecology and Department of Pediatrics B *, \\ Central Emek Hospital, Afula, Israel
}

\section{Introduction}

Premature delivery is the single most important obstetrical complication associated with perinatal mortality and morbidity. An additional one or two weeks of intrauterine existence may decrease neonatal morbidity and mortality. The physiologic aspects of the onset of labor remain an enigma to modern medicine. The exact cause and mechanism of the inhibition of human parturition are unknown and many theories have been advanced to explain the onset of labor: oxytocin, alpha catecholamins, progesterone drop, estrogen-progesteron ratio elevation, fetal corticosteroids, prostaglandins, changes in uterine blood flow and uterine distension. These factors may also be responsible for premature labor.

The problem of how to inhibit labor is not a new one. Traditionally patients have been treated by bed rest, sedation and avoidance of vaginal examinations. Many drugs have also been used including progestogens [9], ethyl alcohol [7], beta adrenergic drugs [16], magnesium sulphate [26] and diazoxide [15]. The marked cardiovascular side effects of the beta adrenergic receptor stimulants may limit their use in the treatment of preterm labor [3]. A role for prostaglandins in spontaneous labor is suggested by their presence in the amniotic fluid [10] in the blood of humans at the onset of labor [32] and by the observation that exogenously administed prostaglandins can induce labor [11, 12] or abortion $[13,21]$. There is also good evi-

\section{Curriculum vitae}

HENRYK ZUCKERMAN graduated medicine at the Hebrew University Medical School in Jerusalem in 1956. Since 1956 he has worked in Obstetrics and Gynecology Department of the Hadassah University Hospital in Jerusalem. In 1967 he was appointed Dozent. In 1970 he was appointed director of the Obstetrics and Gynecology Department at the Central Emek Hospital - Afula.

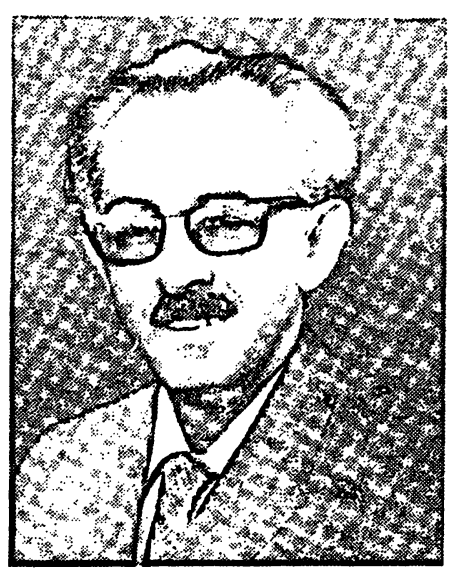
His main research interests are in the field of perinatal medicine.

dence that prostaglandins play an important role in the pathogenesis of premature labor [14].

Prostaglandins synthetase inhibitors are known relaxants of the gravid uterus. The nonsteroid antiinflammatory agents such as aspirin, indomethacin, salicylic acid, naproxen, meclofenamic acid are potent inhibitors of prostaglandin biosynthesis in the body. The purpose of this study was to test the efficacy and safety of indomethacin in suppressing the premature labor and expands a previously reported study [30]. In the first part of the study prospective uncontrolled large group of patients treated with indomethacin for premature labor were evaluated for efficacy and safety and in second part (see the following article) a double blind study was conducted. 


\section{Materials and methods}

A trial of indomethacin was conducted in 297 women in premature labor. The patients were aged between 16 and 44 years. There were 120 primiparas and 177 multiparas. The gestational age at admission varied between 24 and 34 completed weeks of pregnancy. There were 45 patients with premature rupture of membranes. Patients were admitted to the trial if regular, painful contractions were occurring at frequency of two or more in 10 minutes. In all patients uterine activity was recorded with external cardiotocography during a control period of at least 30 minutes to obtain a baseline of activity before indomethacin was administered. Patients with suspected intra-uterine growth retardation, toxemia, uterine malformations, fever, vaginal bleeding, oligohydramnios and polyhydramnios were excluded. Every patient received $100 \mathrm{mg}$ of indomethacin (rectally) in suppository form followed by $25 \mathrm{mg}$ (orally) every 6 hours until the contractions had been inhibited for 24 hours. If uterine contractions continued after the initial rectal dose of indomethacin the patient received an additional $100 \mathrm{mg}$ suppository after 1 hour and then the treatment was continued orally. The total daily dose needed for successful treatment was between 200 and $300 \mathrm{mg}$ of indomethacin and the patient was under hospital observation during 1 to 2 days. No other drugs were used and all patients gave informed consent to the study. Treatment was considered to have been successful when the premature contractions were arrested completely for more than 1 week. Where uterine activity ceased for between 48 hours and
7 days, treatment was considered to be of moderate value. The treatment was considered ineffective if contractions could not be stopped or if they commenced again and delivery took place within 48 hours of the start of therapy. Maternal pulse and blood pressure, uterine contractions and fetal heart rate were monitored during treatment. The criterion for prematurity was a birth age of less than 37 weeks gestation confirmed at delivery by the criteria described by DUBOWITZ et al. [6].

\section{Results}

The effect of indomethacin treatment on premature labor was evaluated by cessation of uterine contractions and the period of prolongation of gestation. Thirty minutes after indomethacin administration uterine contractions decreased in frequency and intensity and complete uterine relaxation was noted within $2-13$ hours. Tab. I shows the results of indomethacin treatment. After indomethacin treatment premature labor stopped completely for 1 to 12 weeks in $83 \%$ of patients. In $10 \%$ the treatment was of moderate value, i.e. the uterine contractions were stopped for 2 to 7 days. The $7 \%$ of the patients in which the treatment was ineffective were delivered in 48 hours. Indomethacin was less effective in cases in which the cervix was dilated more than $4 \mathrm{~cm}$ whereas uterine contractions were arrested completely in $90 \%$ of the cases where the cervical dilatation was $3 \mathrm{~cm}$ or less. When the dilation was more than $3 \mathrm{~cm}$ the contractions were stopped in only $58 \%$ of the cases. Premature labor also more

Tab. I. Results of indomethacin treatment for premature labor in relation to status of membranes and cervical dilation.

\begin{tabular}{|c|c|c|c|c|c|c|c|}
\hline & \multirow{3}{*}{$\begin{array}{l}\text { No. of } \\
\text { patients }\end{array}$} & \multicolumn{6}{|c|}{ Duration of repression of labor } \\
\hline & & \multicolumn{2}{|l|}{$>7$ days } & \multicolumn{2}{|c|}{48 hours -7 days } & \multicolumn{2}{|l|}{$<48$ hours } \\
\hline & & No. of patients & $\%$ & No. of patients & $\%$ & No. of patients & $\%$ \\
\hline $\begin{array}{l}\text { Total No. of patients } \\
\text { Cervical dilation }\end{array}$ & 297 & 246 & 83 & 30 & 10 & 21 . & 7 \\
\hline $\begin{array}{l}0-3 \mathrm{~cm} \\
\geqslant 4 \mathrm{~cm} \\
\text { Membranes }\end{array}$ & $\begin{array}{r}225 \\
72\end{array}$ & $\begin{array}{r}204 \\
42\end{array}$ & $\begin{array}{l}90 \\
58\end{array}$ & $\begin{array}{l}13 \\
17\end{array}$ & $\begin{array}{r}6 \\
24\end{array}$ & $\begin{array}{r}8 \\
13\end{array}$ & $\begin{array}{r}4 \\
18\end{array}$ \\
\hline $\begin{array}{l}\text { Intact } \\
\text { Ruptured }\end{array}$ & $\begin{array}{r}252 \\
45\end{array}$ & $\begin{array}{r}222 \\
24\end{array}$ & $\begin{array}{l}88 \\
53\end{array}$ & $\begin{array}{r}25 \\
5\end{array}$ & $\begin{array}{l}10 \\
11\end{array}$ & $\begin{array}{r}5 \\
16\end{array}$ & $\begin{array}{r}2 \\
35\end{array}$ \\
\hline
\end{tabular}


readily suppressed in women with intact membranes $(88 \%)$ compared with those with ruptured membranes (53\%). In most cases the delay in delivery ranged from 5-9 weeks although in 49 patients delivery was delayed as much as $11-12$ weeks (Tab. II). In 48 patients it was necessary to repeat the treatment as contractions reappeared after 2 week interval.

Fifty-one premature babies were born in spite of therapy and 15 of these ( $5 \%$ of the all group) died from respiratory distress syndrome (weights of $700-1500 \mathrm{~g}$ ). The remaining 36 premature infants and the 246 mature infants were in good condition at birth and were all examined by a pediatrician. Meconium was noted in the amniotic fluid in 18 cases $(6 \%)$ and no ill effects relating to the treatment were observed. The development of these children who were seen at follow-up examination during a period of up to 5 years of age, was satisfactory.

Where labor was not supressed the course of labor and delivery was completely normal with no increased need for obstetrical interference. Indomethacin therapy did not alter maternal blood pressure or pulse rate or fetal heart rate. Minor side effects were seen however including nausea, vomiting and dyspepsia ( 8 patients), maculopapular eruption ( 2 patients) and epistaxis ( 1 patient). All symptoms disappeared within a few hours of discontinuing therapy.

Tab. II. Indomethacin treatment for premature labor and delay in delivery.

\begin{tabular}{llr}
\hline $\begin{array}{l}\text { Delay in delivery } \\
\text { (weeks) }\end{array}$ & No. of patients & $\%$ \\
\hline 1 & 53 & 17.9 \\
2 & 17 & 5.7 \\
3 & 11 & 3.7 \\
4 & 16 & 5.4 \\
5 & 25 & 8.4 \\
6 & 31 & 10.4 \\
7 & 20 & 6.8 \\
8 & 36 & 12.1 \\
9 & 28 & 9.4 \\
10 & 11 & 3.7 \\
11 & 21 & 7.1 \\
12 & 28 & 9.4 \\
\hline Total & 297 & 100.0 \\
\hline
\end{tabular}

\section{Discussion}

The intruduction of indomethacin as an inhibitor of labor resulted from animal and human studies which indicated that prostaglandins play an important role in parturition. Inhibition of production and release of prostaglandin by administration of aspirin or indomethacin has been shown to be associated with inhibition of labor and prolonged parturition in the rat [1] and delay of midtrimester abortion induced by hypertonic saline in the human [27]. It is also known that patients taking salicylates chronically during pregnancy have a higher incidence of gestation beyond 42 weeks [5], and indomethacin has been shown to delay the onset of parturition in pregnant rhesus monkeys [19]. Indomethacin was shown to have an inhibitory effect on prostaglandin synthesis or release and decrease of plasma level of $\mathrm{PGF}_{2 \mathrm{a}}$ after 3060 minutes of its administration [31].

Our study of 297 women shows that indomethacin completely inhibited premature labor in $83 \%$ of the patients. A moderate effect was achieved in $10 \%$ of patients and this delay of premature labor for 2 to 7 days allowed the administration of betamethasone in an attempt to improve fetal lung maturity. The inhibitory effect of indomethacin on uterine contractions and the subsequent delay of delivery, decreased with the progress of cervical dilatation and with the presence of ruptured membranes. These results compare favorably with other reported series using oral indomethacin alone $[4,29]$ or oral therapy following unsuccessful administration of beta-sympathomimetic agents [8]. The total dose administered was usually higher and the duration of administration was usually longer in these series however.

The main theoretical problem associated with the administration of indomethacin is the possibility of this agent causing premature closure of the ductus arteriosus. Case reports claiming to demonstrate a correlation between the ingestion of prostaglandin antagonists and congenital ductus closure [2], and primary neonatal pulmonary hypertension [17] are not well substantiated and do not take into account the thousands of women suffering from rheumatoid arthritis who are exposed to large doses of these drugs during pregnancy without any apparent deleterious effect on 
the fetal circulation. SHAPIRO et al. [22] reported that among 40,000 pregnant women $(25,000$ were treated with aspirin and 15,000 were a control group) no change in perinatal mortality was seen.

A variation in the sensitivity of the ductus arteriosus to indomethacin at different gestations in the rat has been clearly demonstrated by SHARPE et al. [23, 24]. Maximal sensitivity to this drug was found only when it was adminstered 12-18 hours prior to delivery at term, whereas administration at 18 days of age (premature) had no effect at all.

The lack of deleterious effect on the cardiovascular system in our group of infants may have been due to the fact the indomethacin was not given when the gestation exceeded 35 weeks, and similar reasons could explain the lack of complications reported by other workers using indomethacin to inhibit premature labor $[4,8,18,25$, 29]. It is of interest, however, that even when indomethacin was administered within 24 hours of delivery at term [20] no fetal cardiovascular complications occurred. Because of the virtual complete absence of maternal side effects, patient acceptance of the therapy is much higher than when treatment with beta-adrenergic drugs has been proposed.

\section{Summary}

Prematurity still remains one of the unsolved problems in obstetrics and is responsible for a majority of cases of perinatal morbidity and mortality. The use of indomethacin to stop uterine contractions and prevent premature delivery is based on the observation that indomethacin inhibits the release of prostaglandin which is assumed to play a role in the induction and continuation of labor. The effect of indomethacin as an antagonist to prostaglandin was evaluated in a series of 297 women in premature labor. The gestational age at admission varied between 24 and 34 weeks of pregnancy (120 primiparas and 177 multiparas). In $83 \%$ of cases there was complete cessation of labor for a period of 1 to 12 weeks, in $10 \%$ of cases from 2 to 7 days and in $7 \%$ there was no effect. The delay of premature labor for 2 to 7 days allowed the administration of betamethasone in an attempt to improve fetal lung maturity. The total daily dose needed for successful treatment was between $200-300 \mathrm{mg}$ indomethacin. Dilation of cervix beyond $4 \mathrm{~cm}$ was associated with successful treatment in $58 \%$ compared to $90 \%$ if

cervix was dilated $3 \mathrm{~cm}$ or less. In comparing women with intact membranes to women with ruptured, the success rate in suppressing premature labor was significant; $88 \%$ versus $53 \%$. In 49 patients delivery was delayed 11-12 weeks.

Fifty-one babies were born in spite of therapy, and of these 15 with birth weights of 700-1500 g suffered from respiratory distress syndrome and died. All the rest (36 premature and 246 mature infants) showed no ill effects related to the treatment. During a 5 years followup period of these children, normal development was seen in all cases. No intoward effects were observed on maternal or fetal wellbeing during and after treatment. Minor side effects such as nausea, vomiting and dyspepsia occured in 8 patients, a maculopapular eruption occured in 2 patients and epistaxis in 1 patient. These side effects disappeared a few hours after stopping the medication. The results suggest that indomethacin is an effective and well tolerated inhibitor of premature labor.

Keywords: Indomethacin, premature labor, prostaglandin synthetase inhibitor, uterine contractions.

\section{Zusammenfassung}

Weitere Untersuchungen zur Hemmung vorzeitiger Wehen durch Indometacin - Teil I

Frühgeburten gehören $\mathrm{zu}$ den ungelösten Problemen in der Geburtshilfe; sie verursachen die Mehrzahl der Fälle von perinataler Morbidität und Mortalität. Der Einsatz von Indometacin zur Wehenhemmung und Verhinderung vorzeitiger Geburt basiert auf der Beobachtung, daß Indometacin die Freisetzung von Prostaglandinen, die scheinbar für die Geburtseinleitung und ihren Ablauf von Bedeutung sind, hemmt. Der in Bezug auf die Prostaglandine antagonistische Effekt des Indometacins wurde bei 297 Frauen mit drohender Frühgeburt untersucht. Das Gestationsalter bei Aufnahme lag zwischen der 24. und 34. Schwangerschaftswoche $(120$ Erstgebärende und
177 Mehrgebärende). Bei $83 \%$ der Fälle wurden die Wehen über einen Zeitraum von 1 bis zu 12 Wochen gehemmt, bei $10 \%$ von 2 bis 7 Tagen und bei $7 \%$ wurde kein Effekt erzielt. Die Verzögerung der Geburt um 2 bis 7 Tage ermöglichte die Gabe von Betamethason zur Induktion der Lungenreifung. Für eine suffiziente Behandlung mußte täglich eine Gesamtdosis von 200$300 \mathrm{mg}$ Indometacin verabreicht werden. War der Muttermund mehr als $4 \mathrm{~cm}$ geöffnet, so war die Therapie in $58 \%$ der Fälle erfolgreich, während bei einer Muttermundsöffnung von $3 \mathrm{~cm}$ und weniger ein Behandlungserfolg bei $90 \%$ erreicht werden konnte. Vergleicht man die Ergebnisse bei Frauen mit und ohne Blasensprung, so war der Unterschied signifikant: $53 \%$ versus $88 \%$. Bei 49 Patien- 
tinnen konnte die Geburt um 11 bis 12 Wochen hinausgezögert werden.

In 51 Fällen kam es trotz der Therapie zur Geburt; 15 Neugeborene mit einem Geburtsgewicht zwischen 700 und $1500 \mathrm{~g}$ hatten ein RDS und verstarben. Die übrigen Kinder (36 Frühgeborene und 246 reife Neugeborene) zeigten keine Symptome, die mit der Therapie in Zusammenhang gebracht werden konnten. Die Kinder wurden über einen Zeitraum von 5 Jahren beobachtet; in allen Fällen sahen wir eine normale Entwicklung.
Während und nach der Therapie schien der mütterliche und fetale Zustand nicht beeinträchtigt. Bei 8 Patientinnen wurden Nebenwirkungen wie Übelkeit, Erbrechen und Durchfall beobachtet, bei 2 Patientinnen trat ein makulo-papulöses Exanthem auf und 1 Patientin hatte eine Epistaxis. Diese Nebenwirkungen verschwanden wenige Stunden nach Absetzen der Medikation. Die Ergebnisse zeigen, daß Indometacin ein effektiver und gut verträglicher Hemmst off vorzeitiger Wehen ist.

Schlüsselwörter: Indometacin, Prostaglandinsynthetase-Hemmstoff, Uteruskontraktionen, vorzeitige Wehen.

\section{Résumé}

Etude complémentaire du blocage de l'accouchement prématuré par l'indométacine - I

La prématurité demeure encore un des problèmes non résolus en obstétrique et est responsable de la majeure partie des cas de morbidité et de mortalité périnatales. L'utilisation de l'indométacine pour arrêter les contractions utérines et éviter l'accouchement prématuré est fondée sur l'observation de l'inhibition que ce médicament entraîne, de la libération des prostaglandines supposées, joue un rôle dans l'induction et la poursuite de l'accouchement. L'effet antagoniste des prostaglandines de l'indométacine a été étudié sur une série de 297 femmes en travail prématurément. L'âge gestationnel à l'admission était compris entre 24 et 34 semaines de grossesse (120 promipares et 177 multipares). Dans $83 \%$ des cas, il y eut un arrêt complet du travail pour une durée de 1 à 12 semaines, dans $10 \%$ des cas pour une durée de 2 à 7 jours et dans $7 \%$ des cas il n'y eut aucun effet. Le délai de 2 à 7 jours avant l'accouchement rend possible l'administration de Bétaméthasone afin d'améliorer la maturité pulmonaire fœtale. La dose quotidienne nécessaire pour un traitement efficace est comprise entre 200 et $300 \mathrm{mg}$ d'indométacine. A partir de $4 \mathrm{~cm}$ de dilatation cervicale le traitement a été efficace dans $58 \%$ des cas alors qu'il a été efficace dans $90 \%$ des cas lorsque la dilatation était inférieure ou égale à $3 \mathrm{~cm}$. Si l'on compare les patientes avec membranes intactes et les patientes avec une rupture, le pourcentage de succès de prévention de l'accouchement prématuré est significativement différent: $88 \%$ contre $53 \%$. Chez 49 patientes le délai avant l'accouchement a été de 11 à 12 semaines.

55 enfants sont nés malgré le traitement, et parmi eux, 15 avec un poids de naissance compris entre 700 et $1500 \mathrm{~g}$ ont présenté un syndrome de détresse respiratoire et sont morts. Tous les autres (36 prématurés et 246 enfants à terme) ne présentèrent pas d'effets secondaires néfastes en rapport avec le traitement. Un développement normal a été observé dans tous les cas avec un recul de 5 ans de surveillance de ces enfants. On a observé aucun effet secondaire sur le bien-être fœtal ou maternel pendant et après le traitement. Des effets minimes secondaires tels que nausées, vomissements et dyspepsie sont survenus chez 8 patientes, une éruption maculo-papulaire a été vue chez 2 patientes et un épistaxis chez 1 patiente. Ces effets secondaires ont disparu quelques heures après l'arrêt du traitement. Ces résultats suggèrent que l'indométacine représente un inhibiteur efficace et bien toléré de l'accouchement prématuré.

Mots-clés: Accouchement prématuré, contractions utérines, indométacine, inhibiteur de la synthèse des prostaglandines.

Bibliography see part II. 
